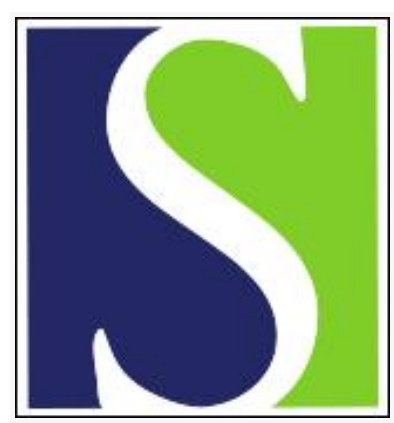

Scand J Work Environ Health 1983;9(4):367-368

https://doi.org/10.5271/sjweh.2400

Issue date: Aug 1983

Occupational exposure to benzyl chloride and benzyl chloride due to contaminated butyl benzyl phthalate.

by Rittfeldt L, Ahlberg MS, Zingmark PA, Santesson J

This article in PubMed: www.ncbi.nlm.nih.gov/pubmed/6635615

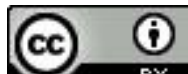




\section{Occupational exposure to benzyl chloride and benzal chloride due to contaminated butyl benzyl phthalate}

Benzyl chloride and benzal chloride were detected as air pollutants in a vinyl floor tile industry. The investigation was performed in order to find the cause of irritation in the upper airways of the workers in this industry. The findings are of particular interest since both benzyl and benzal chloride have been shown to produce irritation of the eyes and respiratory mucosa (5), symptoms like those the workers complained of. Furthermore both compounds have been shown to be carcinogenic in experimental animals and mutagenic in bacteria, benzal chloride being the more potent $(1,3,4,9,10)$. Benzyl and benzal chloride are included in the list of carcinogenic substances from the National Board of Occupational Safety and Health, Sweden. The hygenic standard for benzyl chloride is $5 \mathrm{mg} / \mathrm{m}^{3}$. For benzal chloride no standard is given, and special permission is needed for the handling of this substance and materials containing more than $1 \%$ of it by weight (6).

Vinyl floor tiles are manufactured by the process of laminating a surface film and a patterned film of polyvinyl chloride with a thicker sheeting of polyvinyl chloride at temperatures of $150-180^{\circ} \mathrm{C}$. The surface and the patterned films contain about $30 \%$, by weight, of butyl benzyl phthalate as a plasticizer, and in the thicker sheeting di(2-ethylhexyl)phthalate is used. Exposure levels at a manufacturing line were found to be about $0.03 \mathrm{mg} / \mathrm{m}^{3}$ for benzyl chloride and about $0.15 \mathrm{mg} / \mathrm{m}^{3}$ for benzal chloride. For a determination of the source of these substances the materials used in the manufacturing were analyzed. Benzyl and benzal chloride were found to be present as impurities in the butyl benzyl phthalate used in the manufacturing of the surface and the patterned films. The concentrations of benzyl and benzal chloride, respectively, were as follows: butyl benzyl phthalate: 0.03 and $0.3 \%$; surface film.
0.004 and $0.04 \%$; patterned film: 0.004 and $0.02 \%$; and in the top layer of a 10-day-old vinyl floor tile: $<0.001$ and $0.01 \%$. In butyl benzyl phthalate, benzal chloride has not previously been reported, and the concentration of benzyl chloride has been determined to be less than $0.01 \%$ (8). A measurement of the exposure level at the factory producing the surface film has also been performed. The concentrations in air were found to be around $0.03 \mathrm{mg} / \mathrm{m}^{3}$ for benzyl chloride and around $0.2 \mathrm{mg} / \mathrm{m}^{3}$ for benzal chloride. Both substances were also detected in the atmosphere over a 10-dayold vinyl floor tile. At room temperature the emission rate of benzal chloride was calculated to be about $0.01 \mathrm{mg}$ per hour and square meter. Dichlortoluenes have earlier been found in the vapors from vinyl floor tiles, but no specification of benzal chloride was made (2).

Commercial production of butyl benzyl phthalate is usually performed by the reaction of the monobutyl ester of phthalic acid with benzyl chloride, which may contain up to $1 \%$ benzal chloride (4). In our analyses the concentrations of benzyl and benzal chloride in different brands of butyl benzyl phthalate have been found to vary between 0.01 and $0.05 \%$ and between 0.001 and $0.4 \%$, respectively, probably due to different levels of purification. Thus it seems possible to reduce the exposure levels of benzyl and benzal chloride by using butyl benzyl phthalate with low levels of impurities, and such a conversion is presently going on in Sweden.

Potentially exposed occupational groups in Sweden include workers in the plants producing surface films and vinyl floor tiles, as well as floor-layers. Vinyl floor tiles made from polyvinyl chloride plasticized with butyl benzyl phthalate are easy to clean, and for this reason they are often used in public buildings like daycare centers, schools, hospitals, and office buildings. Since vinyl floor tiles have been shown to emit benzyl and benzal chloride, a certain exposure of the general pubic may occur. This emission may be a factor contributing to the irritations experienced 
in so-called "temporary sick buildings."

The exposure levels of benzyl and benzal chloride found so far seem to be low, but a great number of people are exposed due to the large amounts of butyl benzyl phthalate produced. In the United States the production in 1979 was estimated to have been $68 \times 10^{6} \mathrm{~kg}$, more than half of which was used for vinyl floor tiles (4). In Sweden approximately $2 \times 10^{6} \mathrm{~kg}$ of butyl benzyl phthalate is used yearly. According to an estimation of the National Institute for Occupational Safety and Health (7) over 60,000 workers in the United States are potentially exposed to this plasticizer. A reduction of the exposure to benzyl and benzal chloride due to contaminated butyl benzyl phthalate must be considered as urgently needed.

We are presently undertaking systematic measurements of exposure levels for the potentially exposed occupational groups in Sweden. Butyl benzyl phthalate has been used in Swedish industry for about 20 years, and for future epidemiologic investigations it is important to have reliable data on the exposure. We also intend to repeat our measurements after the conversion to uncontaminated butyl benzyl phthalate has been completed.

\section{Acknowledgment}

This study was financially supported by a grant from the National Board of Occupational Safety and Health, Sweden.

\section{References}

1. Druckrey H, Kruse H, Preussmann R, Ivankovic S, Landschutz C. Cancerogenic alkylating substances: III Alkylhalogenides, -sulphates, -sulphonates and strained heterocyclic compounds [in German]. Z krebsforsch 74 (1970) $241-273$.

2. Ekbladh S, Asnes H. Development of a test method for determination of concentra- tions of volatile substances emitted from materials in the indoor environment [in Swedish]. Report to the Swedish Council for Building Research. Grant no 760917-8, 1982.

3. Fukuda K, Matsushita H, Sakabe H, Takemoto K. Carcinogenicity of benzyl chloride, benzal chloride, benzotrichloride and benzoyl chloride in mice by skin application. Gann 72 (1981) 655-664.

4. International Agency for Research on Cancer. Some industrial chemicals and dyestuff. Lyon 1982. (IARC monographs on the evaluation of the carcinogenic risk of chemicals to man, volume 29).

5. Mikhailova TV. Comparative toxicity of chloride derivatives of toluene: Benzyl chloride, benzal chloride and benzotrichloride [in Russian]. Gig tr prof zabol 8 (1964) 14-19. (Translation in: Fed proc (trans suppl) 24 (1965) T877-T880).

6. National Board of Occupational Safety and Health. Occupational threshold limit values [in Swedish]. Liber, Stockholm 1981. (AFS 1981: 8).

7. National Institute for Occupational Safety and Health. National occupational hazard survey. Division of Surveillance Hazard Evaluations and Field Studies, Cincinnati, OH 1980 , p 107.

8. Novrocik J, Novosadova M. Identification of impurities in benzyl butyl phthalate by gas-liquid chromatography and mass spectrometry. Collection czechoslov chem commun 44 (1979) 2202-2210.

9. Preussman R. Direct alkylating agents as carcinogens. Food cosmet toxicol 6 (1968) $576-577$.

10. Yasou K, Fujimoto S, Katoh M, Kikuchi Y, Kada T. Mutagenicity of benzotrichloride and related compounds. Mutat res 58 (1978) 143-150.

Lars Rittfeldt, BSc, ${ }^{1}$ Mats S Ahlberg, ScD, ${ }^{1}$ Per-Anders Zingmark, MSc, ${ }^{2}$ Johan Santesson, $\mathrm{PhD}^{1}$

1 National Defense Research Institute, NBC Department, S-901 82 Umeå, Swedèn.

2 Labor Inspectorate, Magasinsgatan 1, S-902 47 Umeå, Sweden. 